\title{
FASHION DURING THE 20th CENTURY POST-WAR PERIODS
}

\author{
Marija Kertakova ${ }^{1 *}$, Sonja Jordeva ${ }^{1}$, Kiro Mojsov' $^{1}$ \\ 1 Technological and Technical Faculty, University Goce Delcev Stip, \\ Professional paper \\ UDC: 391.1/92."36" \\ Krste Misirkov b.b., Republic Nort of Macedonia \\ *e-mail: marija.kertakova@ugd.edu.mk \\ doi: $10.5937 /$ tekstind1903029K
}

\begin{abstract}
: 20th century war and post-war periods are a particularly specific time lines that have a dramatic effect on the development of fashion. In the post-war period, the problem of fashion appearance took a back seat. This fact, which affects both sexes equally, is perceived relatively quietly by men but not by women. As always, there are two trends - attraction and repulsion. The first involves the use of military elements in a civilian costume. The second tendency is to create a line that will allow people to shake off as soon as possible the nightmarish memories of the war. The new social ideal of beauty is based on the clear construction and appropriateness of the garment, but it already feels the ebb and flow of the principle of military production - "cheap and easy". The new fashion bows to the elements left behind by cubism and constructivism - rigor, clarity, linearity, volume reduction - after the First and - convenience, combination of the incompatible, kaleidoscope of colors, fabrics and forms - after the Second World War. After the end of the two world wars, the military and pre-war influences were almost forgotten. New generations live their full-blooded lives and are interested in fashionable clothing, and here come the first fashion trends related to youth counterculture. The breakthrough of women in the business world and the trace for emancipation imposes from military emelents, ladies' fashion, to begin to shift towards masculine ones. A new wave of segregation and a special attitude towards a brand new women's business clothing begins.
\end{abstract}

Keywords: 20th century war and post-war periods, militar elements in a civilian costume, new fashion lines, new generations, youth counterculture, women's business clothing.

\section{MODA TOKOM POSLERATNOG PERIODA 20.VEKA}

\begin{abstract}
Apstrakt: Ratna i posleratna razdoblja 20. veka naročito su specifična razdoblja koja dramatično utiču na razvoj mode. U posleratnom periodu problem modnog izgleda je ostavljen po strani. Ovu činjenicu, koja podjednako utiče na oba pola, muškarci relativno mirno doživljavaju, ali ne i žene. Kao i uvek, postoje dva trenda - privlačnost i odbojnost. Prvi uključuje upotrebu militarnih elemenata u civilnom odelu. Druga tendencija je stvaranje linije koja će ljudima omogućiti da se što pre oslobode nemilih uspomena na rat. Novi društveni ideal lepote zasnovan je na jasnoj konstrukciji i prikladnosti odeće, ali već se oseća postepeno slabljenje i protok principa vojne proizvodnje - „jeftino i lako". Nova moda nadovezuje se na elemente koji su ostali nakon kubizma i konstruktivizma - strogost, jasnoća, linearnost, smanjenje obima - posle Prvog i - praktičnost, kombinacija nekompatibilnog, kaleidoskop boja, tkanina i oblika - posle Drugog svetskog rata. Po završetku dva svetska rata, vojni i predratni uticaji skoro su zaboravljeni. Nove generacije žive svoje živote punim plućima i zanima ih moderna odeća a pojavljuju se i prvi modni trendovi vezani za kontrakulturu mladih. Proboj žena u poslovnom svetu i trag emancipacije nameće prelazak sa vojnih elemenata, preko ženske mode, ka muškim elementima. Započinje novi talas segregacije i stvara se poseban odnos prema potpuno novoj ženskoj poslovnoj odeći.
\end{abstract}

Ključne reči: Ratni i posleratni periodi 20. veka, militarni elementi u civilnom kostimu, nove modne linije, nove generacije, kontrakultura mladih, ženska poslovna odeća. 


\section{INTRODUCTION:}

In the twentieth century, wars and revolutions not only did not cease, but they also had a tremendous influence on the entire socio-cultural life - in this sense including fashion. The two world wars are the beginning of a whole new, radically changed social relationship and outlook on life, which set off not the search for the ideal, but make it possible for the personal pursuits and achievements of fashion designers to become ideal. Military action, new social disadvantages lead to the rationalization of clothing, which becomes simply economical and functional (rather than purely aesthetic). The woman begins to play an important role, which results with a change in the very perception of herself as a "woman" - from amusing matron, she transforms herself into an androgenic "boy-ish" vision, a fighter who, equally with men, knows how to move with effort on the front, be a nurse or work typically male jobs. All this causes her to break away from $19^{\text {th }}$ century traditions and to start dressing simpler, more functional, freed from any possible trinkets and curls [1]. Solving the dilemma of appearance, abandoning artificial support structures for the garment leads to a rethinking for the role of the length of the lady's dress, which transforms into a unified, ubiquitous garment that loses its femininity and approaches masculinity and pivotal appearance. The difference between men's and women's clothing reaches the edge of the most basic anthropological differences.

The difference between male and female origins in youth fashion on the other hand, is almost lost to create different types of clothing that meet the requirements of youth fashion culture - so-called "teenage" fashion. They are indeed becoming a booming branch of industry, and their mass is the subject of various social sciences that seek to explore fashion as a complex human phenomenon, aimed at meeting the basic needs of citizens, which, in addition to its utilitarian functions, is beginning to fulfill many others that have a decisive influence. The most significant is the revolution of the pants in the women's fashion - they are making their way and remain permanently in it during the second half of the twentieth century. The revolutionary views of leading fashion designers, backed by technology and the midst of fashion houses in Europe, are creating the conditions for more and more democratization, but for special occasions, the custom of retaining the importance of emphasizing the wearing of garments created in past eras remains. To a large extent, what one wears on a daily basis remains either eclectic or unified by denim clothing, but when one wants to be contemporary and fashionably dressed, there are generally no obstacles to do so.

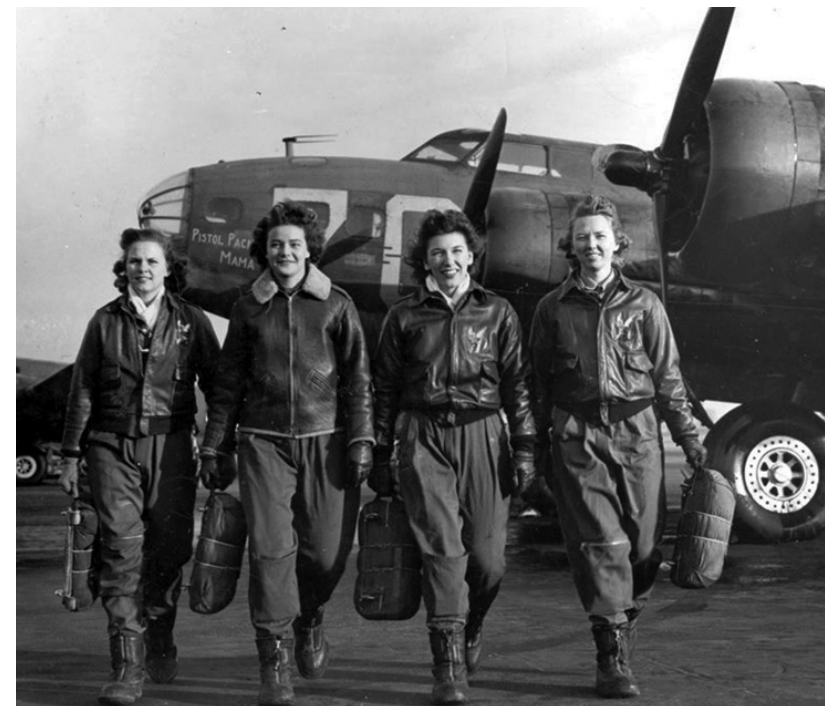

A Women's Airforce Service Pilots flight team walks from the "Pistol Packin' Mama." (1942)

(Photo courtesy/WASP Museum)

\section{FASHION DURING THE FIRST POST-WAR PERIOD:}

A particularly specific period in the development of fashion is the time between the two world wars, which lasts from 1919 to 1928 . It is distinguished by the fact that in post-war development the problem of fashion appearance goes on second plan (passes in the background). This fact, which affects both sexes equally, is perceived relatively calmly by men, but not by women. Rule as always two trends - attraction and repulsion. The first involves the use of military elements in the civil suit, which occurs mostly in the upper cut of clothes. The second tendency is to create such a line that allows people to shake as soon as possible from the nightmares of the war. Moreover, the post-war recovery is proceeding at a rapid pace. There are conditions that are conducive to the entry of young talents born early in the century. They were too young to learn directly from the old coryphaeus or to have notions of pre-war fashion. This allows them to dedicate their talents to fashion with new strength and fresh eye. The other circumstance is that the chemical industry, strongly developed during the war years, is now successfully diversified for the needs of civilian life by producing artificial fabrics, replacing silk. The technology allows mass production, including large-scale production of ready-made clothing, by analogy with sewing a military uniform conveyor.

Seeing the results achieved during war with the help of the technique, the man continues to bow before the technical power after the last bursts of war. The rigid geometric lines of the technical equipment 
are perceived not only by the art of constructivists, but also by the designers of women's clothing. The new public ideal of beauty is based on the clear structure and adequacy of the garment, but already feels retreat from the principle of military production "cheap and easy". Under laconic forms and deceptive simplicity of functionality is emerging a new attitude towards the results of the intensified searches of fashion designers during this period. And they are focused on the trail left by Cubism and Constructivism - rigor, clarity, linearity, diminishing volume [2].

War brings another important change in the relationship between men and women - they are becoming colleagues at work, labor side by side not only in offices but also in workshops and here we must seek the proto-form of feminization of many professions, the result of which we see very clearly today (Figure 1-5).

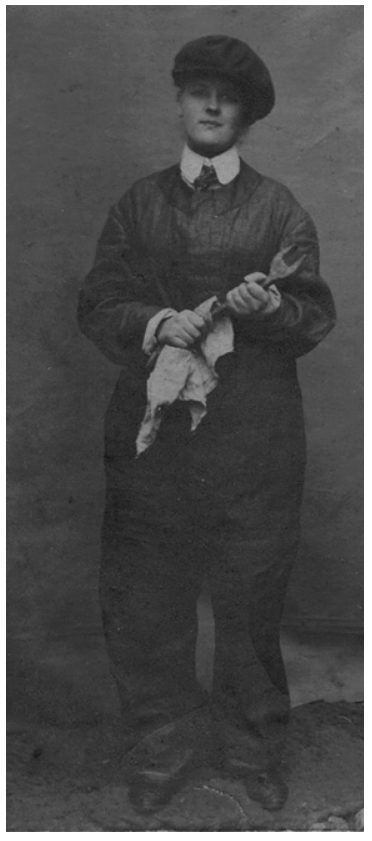

Figure 1: Women in trousers were a shocking but common sight during both war periods

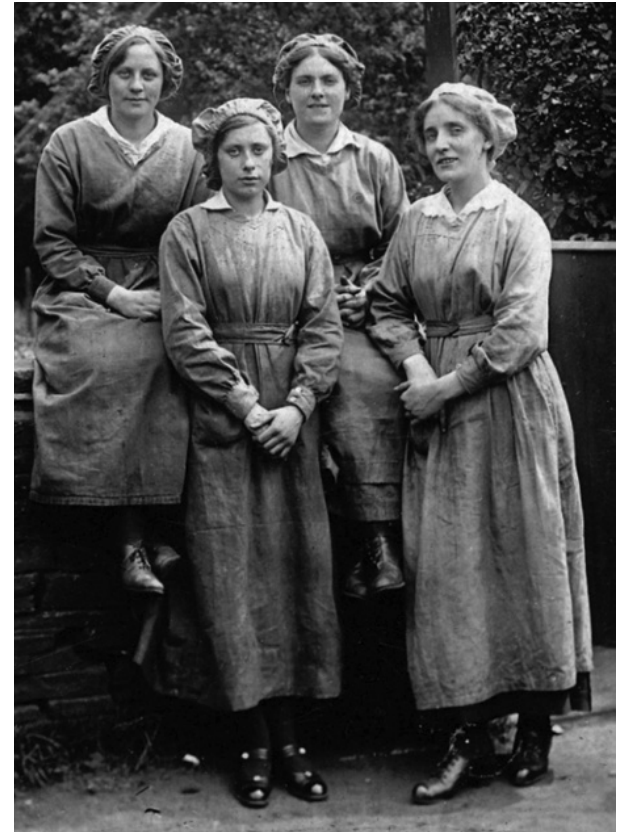

Figure 4: Working women during First World War

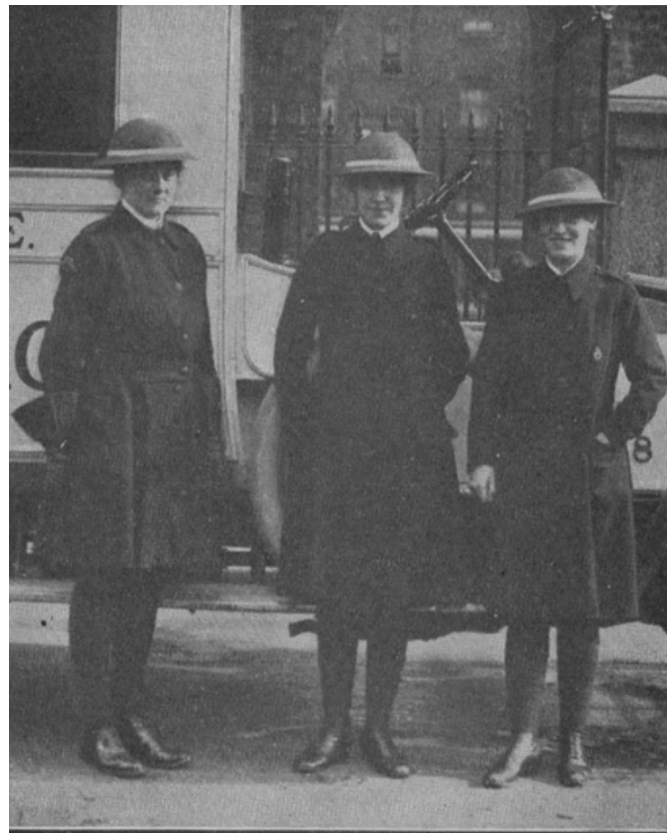

Figure 5: Ambulance drivers in their shrapnel helmets for duty during air raids

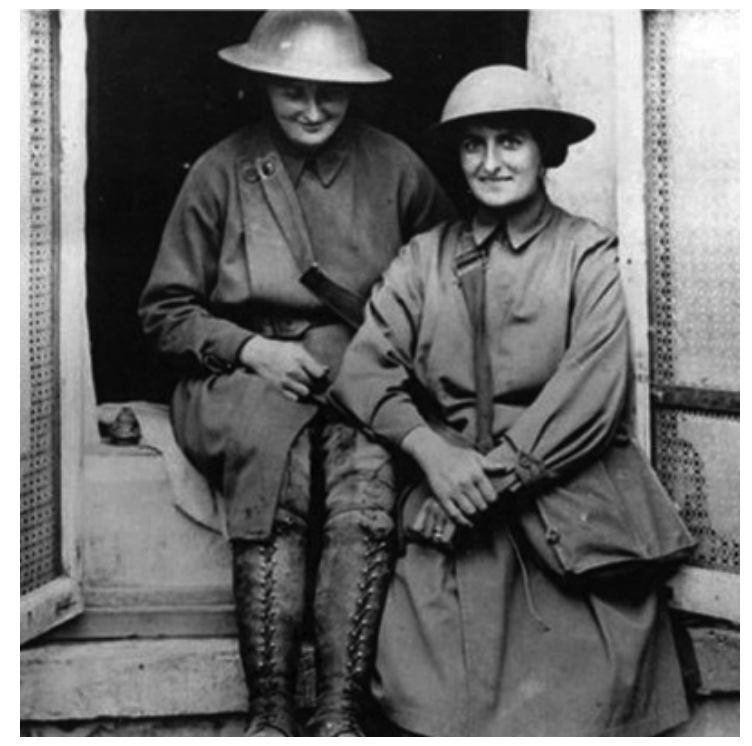

Figure 2: Brave women fight hand by hand with men during First World War

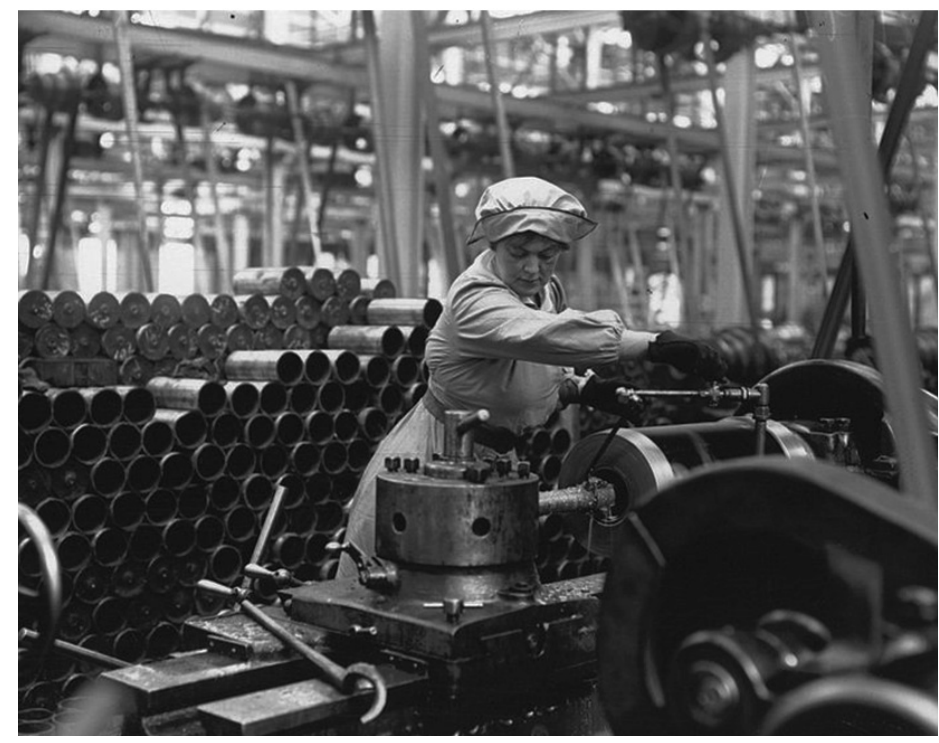

Figure 3: During the war, women had no choice but to take the place of their husbands in factories 
The woman from sultry matron and adored lady patronesa turns into a boy - a reminiscence of the war hat gave rise to this bizarre image: thin, very alive and mobile, with long arms, narrow hips and flat chest with fashion lighted cigarettes, short hairstyle (called again as in the war - a "typhus boy" and in the West, called "babybike") and yet with bright, almost defiant, make-up; with lips that are red in the shape of a heart, she is some sort of "bifocal" combination of an inexperienced adolescent and an experienced woman (Fig. 8-10). The brightest visible expression of this ideal is the famous twin sisters Dolly (Fig. 6).

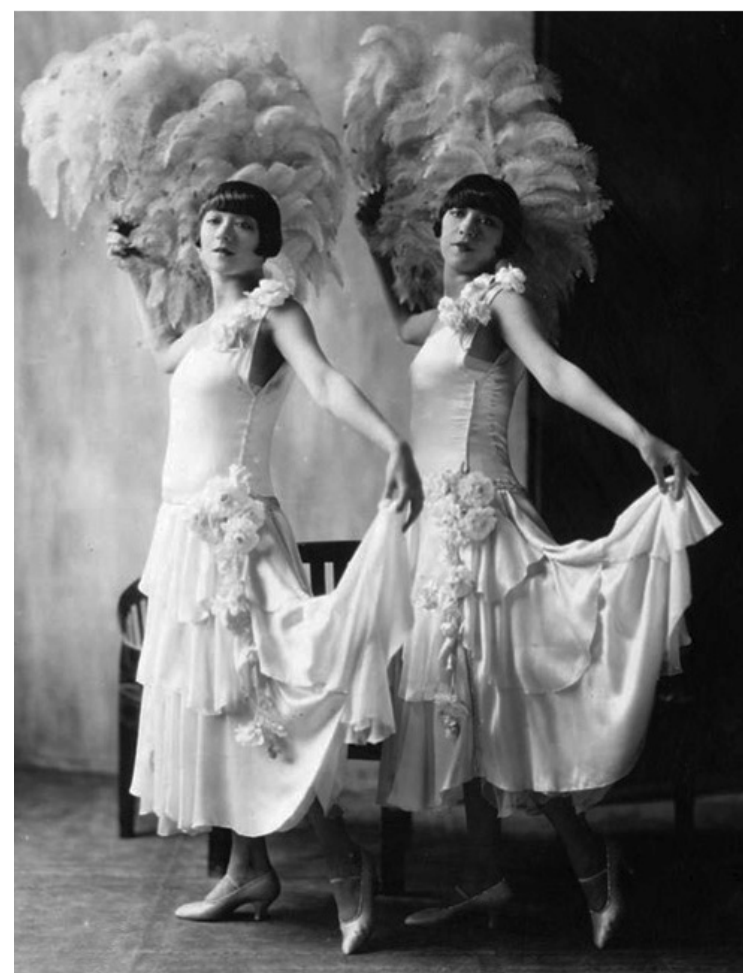

Figure 6: Dolly twin sisters

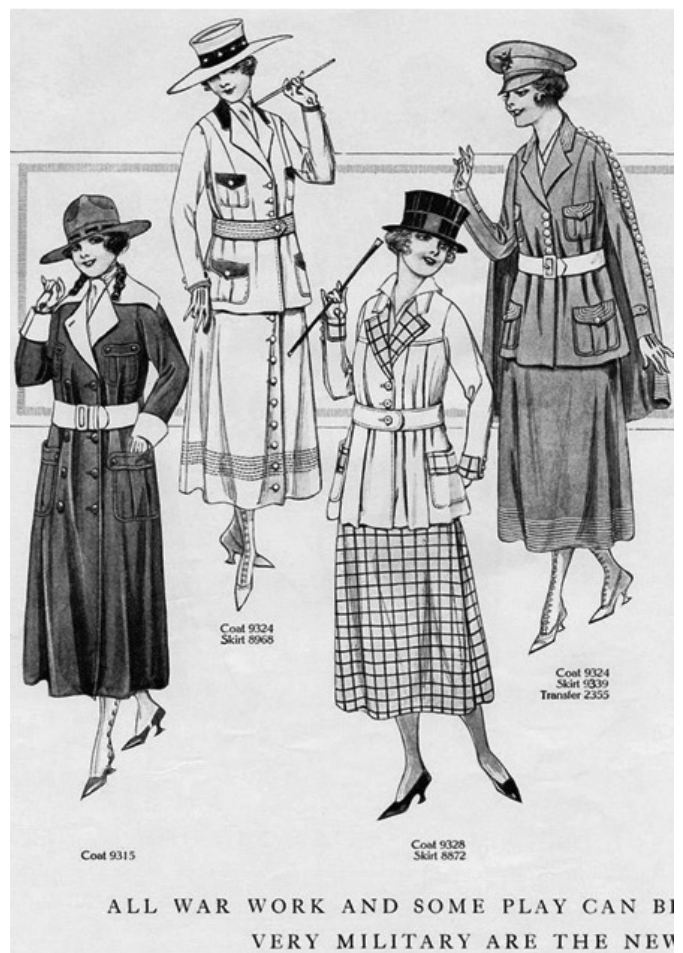

Figure 7: Coat-dress - see figure one
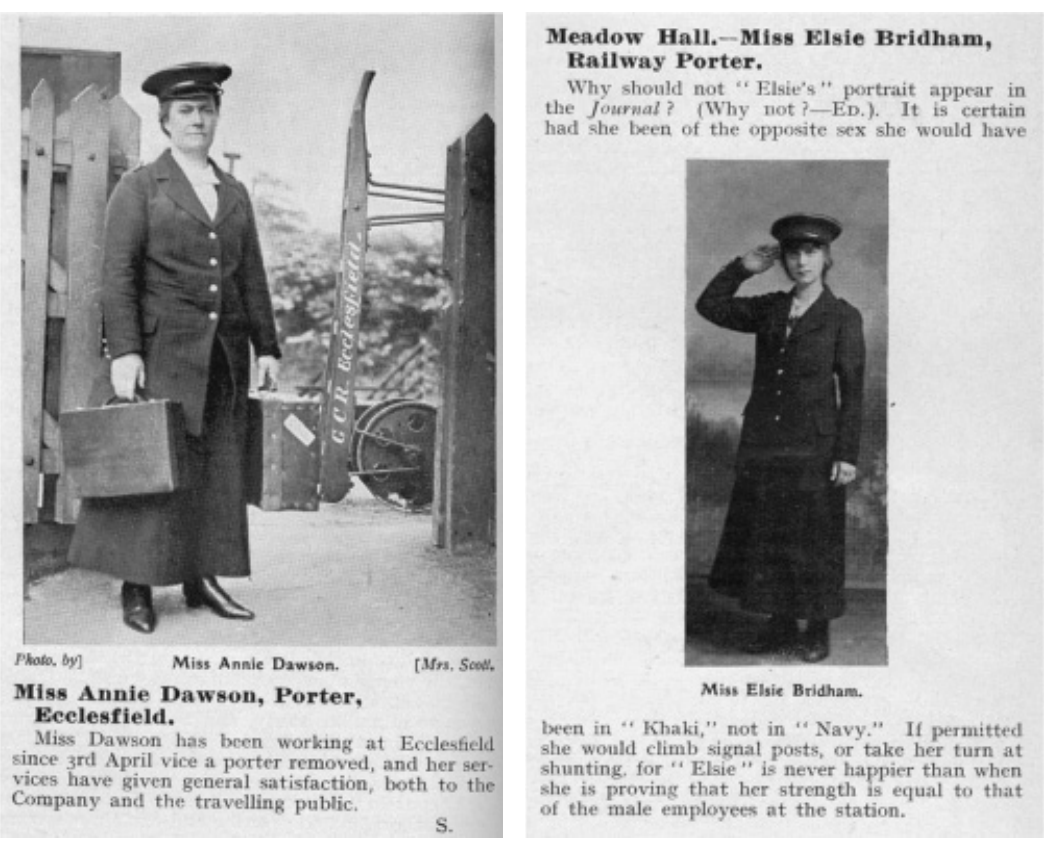

Figure 8-9: Working women during First World War with implemented military emelenst in their clothes

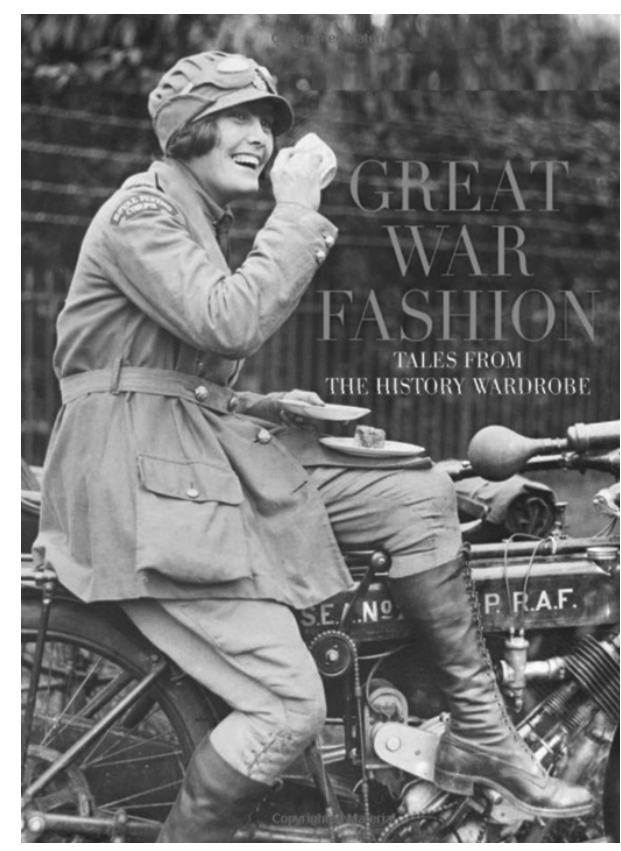

Figure 10: The tendency of military elements implemented into everyday clothing was mutual for both war periods 
For the shaping of the business ladies' suit at that time, Dimitrova-Popska [3] noted the following: „The length of the jacket to the skirts is 1:1. It is very important ... to observe the curved line of the jacket at the bottom with high-fastening enlarged lapel and straight skirts emphasizing the rectangular elongated shape of the silhouette. During this period we also find suits with asymmetrical fastening". She also recommends that when developing modern fashion collections that are thematically designed for everyday business suits, ,.... costumes from 1926 to 1949 can be used. During this period there are various shaped jackets - from loose to tightly with shoulder seams, tailor-made with elongated lapel, fastened with several buttons. The sacks are of different length - long to the hips or shortened to the waist with two-fold fastening" [4]. Unlike the crinoline and bustle era, where the anchor points of the garment are two shoulder belt as a natural support and crinoline, firmly attached around the waist and serving as a second fulcrum, with their removal remains only support for the shoulders. This is why the dresses look like long ladies shirts (Figure 7). During this period, problems of constructive character appeared - to bring out the plastic image of the suit without additional support. This causes the drapings to reappear, but asymmetric patterns are applied to overcome their uniformity. With extreme sharpness, this problem lies in the fash-

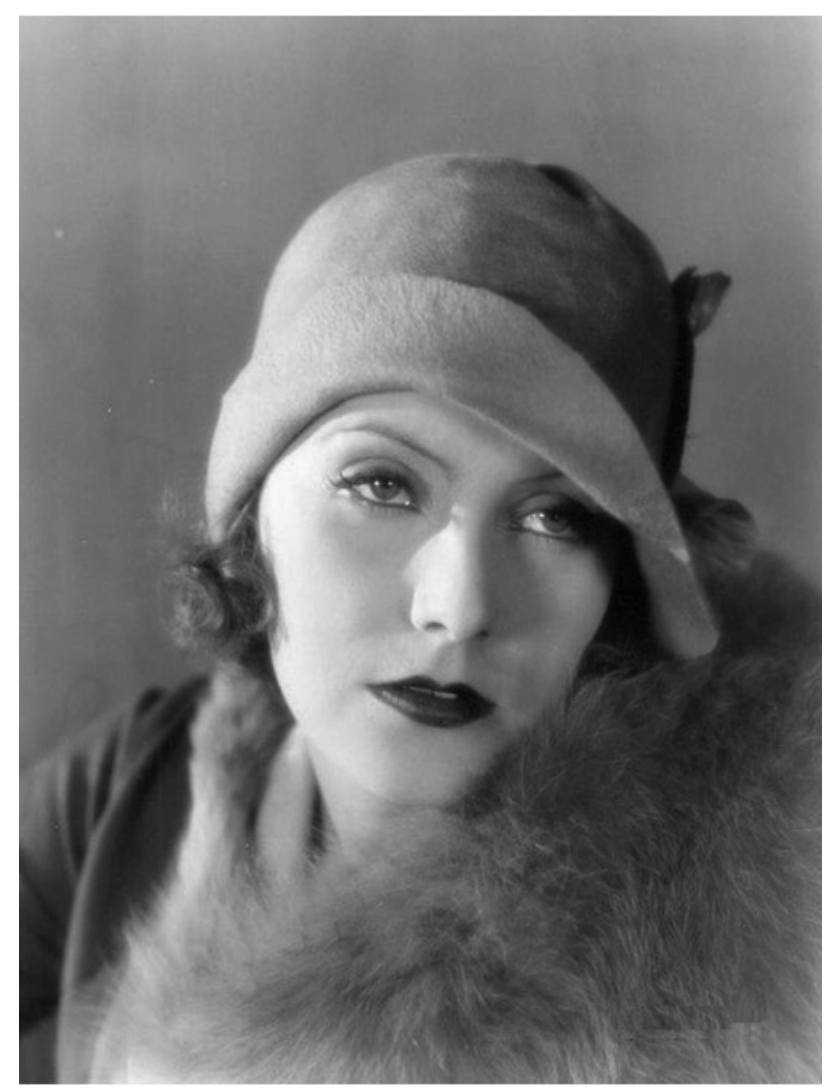

Figure 11: Greta Garbo wearing "Clotche" hat ion line, shaped by a short dress and a short haircut. Here comes the lady's "Clotche" hat and its varieties (Figure 11).

Parisian modelers are well off this new range of problems, putting the issue of creating the women's costume ensemble first, which will be the main problem throughout the $20^{\text {th }}$ century, to all fashion designers without exception.

Over the course of the period, the first attempts to solve this problem are made, as the design strategy is reduced to the following:

(1) striving to create a common color harmony;

(2) a rhythmic distribution of one color perceived as a leading one (most often it is declared as the fashion color of the season), which is implicated both in the main area of the garment and in the accessories (bag, scarf, gloves, hat, rarely jewelry from precious stones and precious metals);

(3) a rigorous internal coherence between the shape and a line, and each designer takes only one of them as a leading role, while the remaining elements are subordinate.

And if the realization of the first two points of the strategy is relatively easy, the realization of the 3rd point becomes quite difficult, because the problems at that time accumulate avalanche - new social relations, new forms of work and leisure, a new pace of life and the search for ideal radically different from the previous. This requires complex design thinking and work, and old prewar designers not only do not realize the problems but cannot even give intuitive solutions. A successful invention in this respect was the established in 1925 coat-dress (Figure 7).

From this point on, the analysis of fashion will take place on problematic nuclei in view of how the designing of the artistic ensemble in the ladies' suit is being solved by the leading designers in different years. An important circumstance here is that in the periods we have seen so far, public forces who are neither artists nor modelers have made the ideal. The work of designers is to wear this ideal in astonishing forms so that it is understandable, and the work of the mass media is to impose and retain this image for a certain time. Industry that deals with fashion, manufactures and sells fashion items is particularly interested in this. 


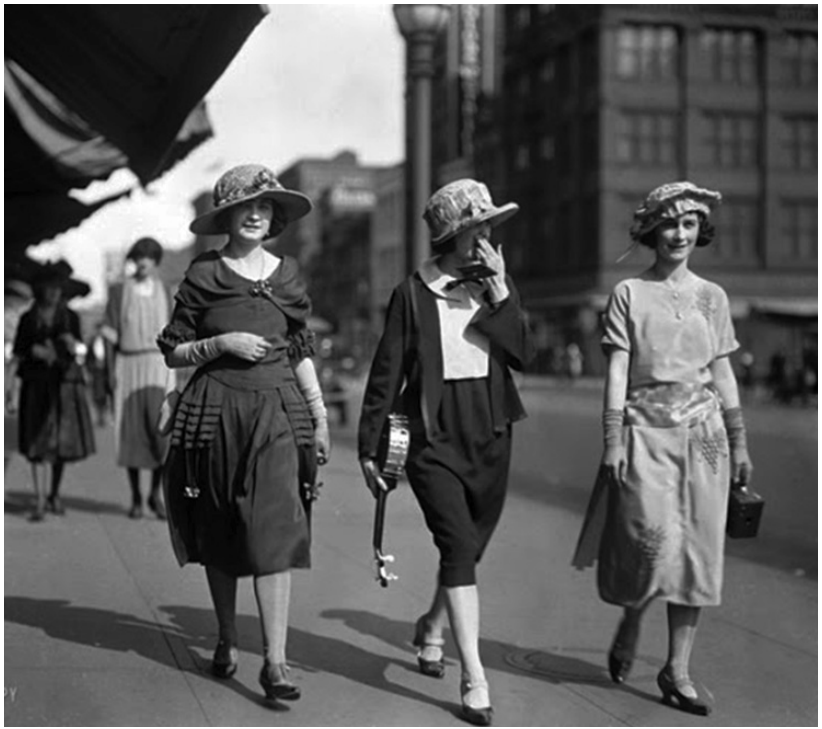

Figure 12: Spring fashion in Easter, Washington, D.C., 1922

\section{FASHION DURING THE SECOND POST-WAR PERIOD:}

After World War II the situation changes. Fashion designers and the mass media have felt their dominance and have developed techniques to effect society by influencing the leaders of public opinion. The ideal is no longer sought, but it is necessary - the fashion line and the fashion design are made by the creation of units - the most gifted, the most charismatic. It is they, the fashion designers imposed over the years, who we have to analyze.

Initially we will focus on the transition period in the 1950s, which is a bridge between the two halves of the century. Although both military conflicts have a revolutionary impact on fashion and accelerate its democratization, there are also significant differences that affect fashion. If during World War I women just occupy the place of the men killed on the front, they are wartime and not only doctors and nurses, but also active participants during the Second World War. In the winning countries, women are also war heroes, like men, embraced by the hall of fame that will be preserved until the early 1960 s. Therefore, we can easily explain the influence of the military line of clothing during these years. The first thing that strikes at critical analysis is that it keeps the silhouette with broad shoulders and a narrow waist (Figure 13 - last model).

The stability of the silhouette with a pointed shoulder strap, shaped with special padding of apparel wool, was also very convenient for the garment manufacturers - so-sewn costumes can be worn without adjustments. The rapid development of Europe's

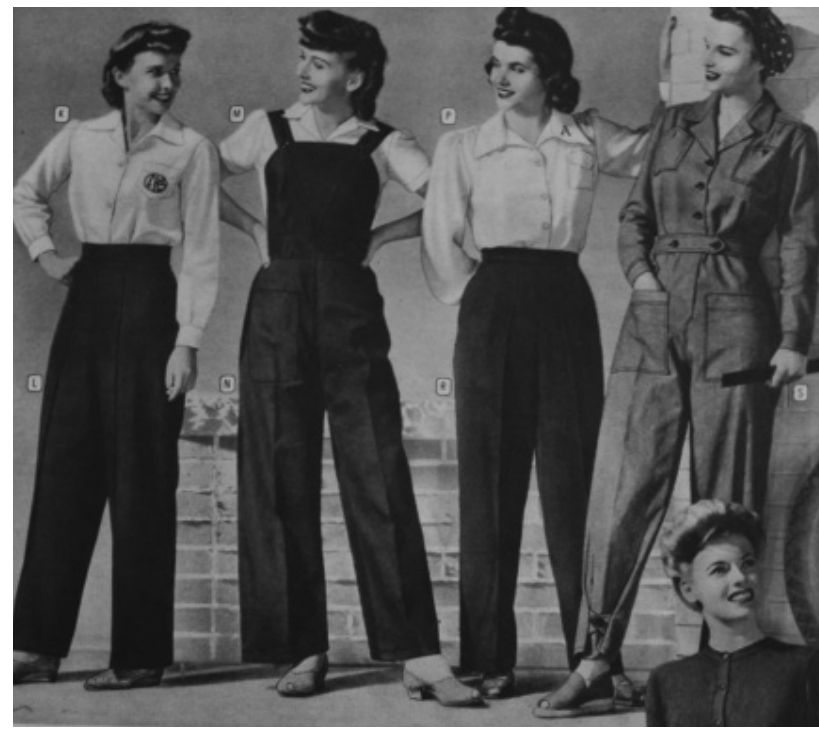

Figure 13: 1943 wide leg pants and blouse, overalls with blouse, tapered pants and blouse, and coveralls with optioned tapered leg cuff

industry (the influence of the Marshall Plan) leads both to generational change - post-war generations search for the new silhouette and find it in three basic configurations - a right elongated rectangle, a triangle placed vertically down on a rectangle, and two triangles with intersecting peaks. Reflections of military suits are also felt in many details - external pockets with lids, wide waistbands or belts, buckles directly descended from military conveyors, cuffs both on the sleeves and at the bottom hems. The tendency is for these "masculinizing" details to be gradually replaced with typical ladies - lace collars, various in design and frog fabrics, ribbons and strips. The hairstyle retains its importance - this decade has a struggle between the hat and the hairstyle, which ends with the victory of the open hair for the ready-made fashion and that is why the hairstyle becomes so important here. However, the hat is reserved for collections of high fashion. Due to the fact that the dress is shorter, the shoes and socks play a significant role in the visible appearance. They are no longer a hidden element, but one that designers will pay great attention to - both shape and color. It is needed to combine several fabrics and colors in one article.

There is also the question of combining and harmonizing different parts of the costume - the hat, the top of the garment (blouse, jacket, bustier) lower part (skirt or part of the dress), socks and shoes. This not only complicates the task but also becomes a field for designers' experiments in the post-war period and until the end of the $20^{\text {th }}$ century. Initially, the designers of the 1960s launched the ideal of a young woman, actively engaged in sports, dressed in mid-or 
low-heeled shoes, short cut (mostly hair-to-shoulder, falling in broad curls) with a bag over her shoulder. But the impact of wartime is felt not only in women's daily but also in the evening dresses. As a rule, they have very small closed necklines, as well as variants with narrow, sleeve-shaped long sleeves. There is another novelty - evening outfits in two parts - a long black skirt combined with a blouse. itary and pre-war influences are almost forgotten. The new generations live their full-blown life and are interested in fashion clothing, and here are the first trends of fashion related to youth counter-culture "Les Incroyables" /The Incredibles/ and "Merveilleuses" /Marvelous/, as if "sleeping" century and a half, find themselves in the fashion first of the hippies and their imitators, and then into the numerous branch-

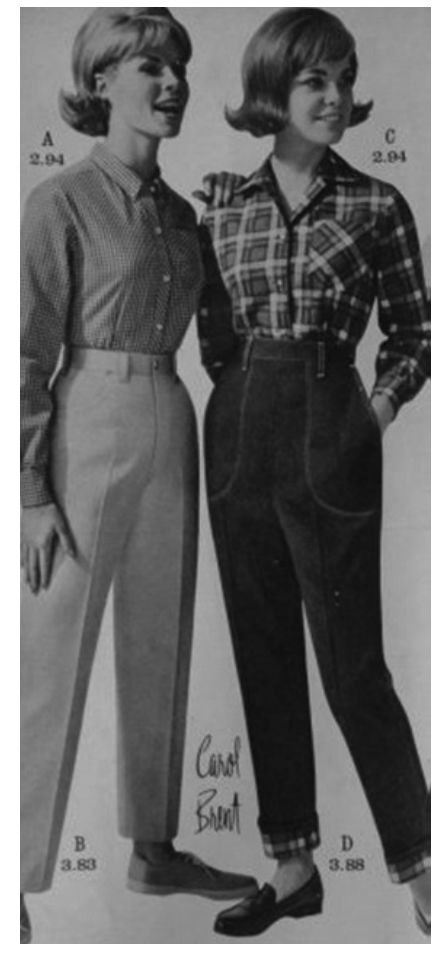

Figure 14.

1964 Women's jeans

Another factor that significantly affects clothing is the wider use of synthetic fabrics. It turns out that synthetics is not only the beginning of a new fashion "language" but also requires new cutting skills because it imposes simple (not to say - elementary) patterns with a minimum amount of stitches on them. To compensate, new fabrics have unseen until that time texture, as well as new and varied colors. The tensile strength of the new synthetic fibers makes it possible to produce extremely thin ladies socks, and the age of the 60 s provides ladies with something really practical and useful - the pantyhose [5], coming down from the stage and permanently housed in everyday lifestyle. Since the end of World War II until the mid 60 s the idea of ensemble suit makes its way and established itself in the fashion of the twentieth century. The question of compatibility is also on the agenda because of the new aesthetic concepts of beauty, which are particularly problematic in the periodicals about clothing fashion in the 1950s and 1960s. Mil- es of youth fashion with their principles - combining the unmatched, kaleidoscope of colors, fabrics and shapes (Figure 16). The explanation of this phenomenon can be found in the culture of the protest, which borrows ideas from the images of the grotesque. On the one hand, it must be scandalous-looking to pay attention - to show that society has problems that need solutions. The explanation is that the original is always some extreme, as the standard here is the core. There should be a narrow distinction between the original and the extravagant. It is in that while the original retains the connection with the core and the nucleus by making new deviations around them, the extravagant one, so to speak, tries to break its umbilical cord with the core, to have nothing to do with it, that is, read in it some super novelty, which according to Freud's followers is explained by the "eruption of deep libidinal energies".

Here we can specify all the variations of hippy and teen fashion. If for high fashion the scene of display 


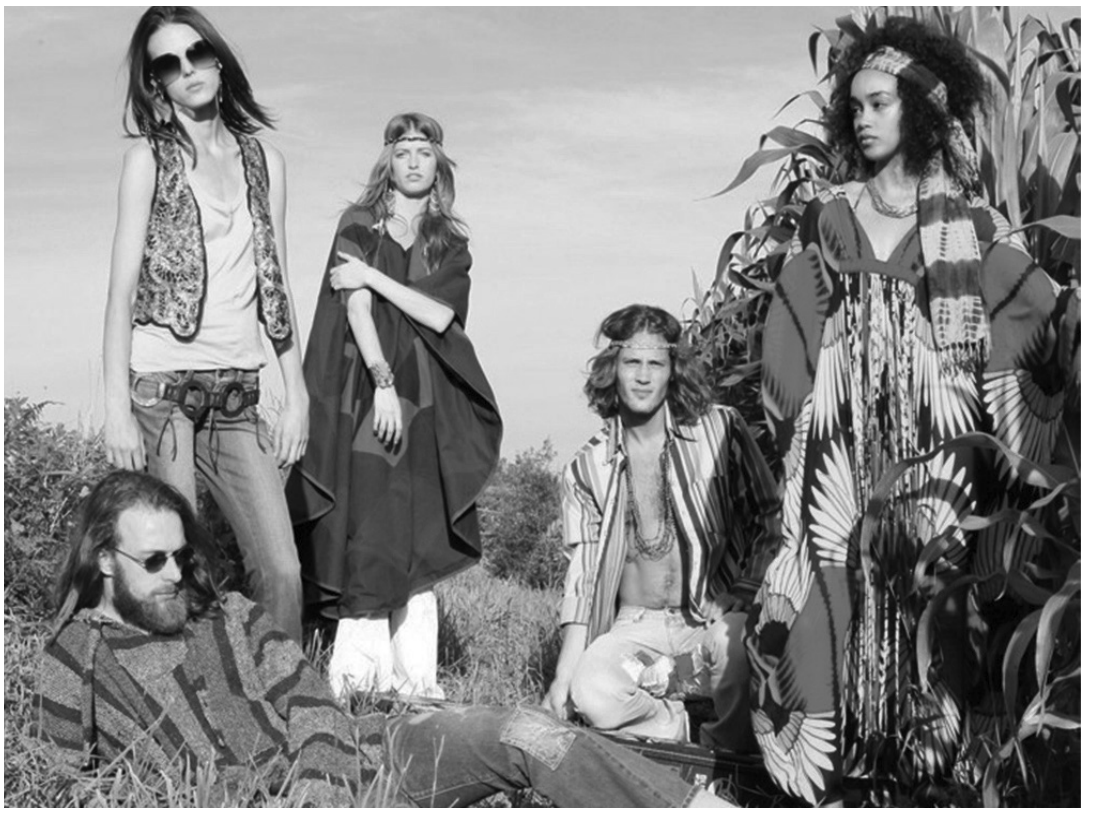

Figure 16. 1970s Hippie fashion
Another trend that affects fashion is working time regulation - a massive eight-hour business day and a five-day work week with a two-day rest are being massively introduced into the civilized world. There is an opportunity for sports and tourism and this is no longer the case for individual rich clubs, but for broad sections of the population, including the upper layers of the middle bourgeoisie. It is the sports suit that originally is the area where the masculine and femininity are converging together and sublimate in the suit.

The scarves (essentially trousers) offered by Poire and greeted

is the fashion defile, then for the counterculture scene is the street hence the name street fashion. It is the general principles of expressing the protest and gaining it a visible image that is the foundation that unites the otherwise far-fledged fashion images from the time of the French Revolution to the times of youth riots and protests against war that have spread both in America and in Europe. The rebellion, however, also has its market price - after it is shown on the pages of the printed publications, its taming begins. The principle is that it is a "rule" from a "mistake" and from

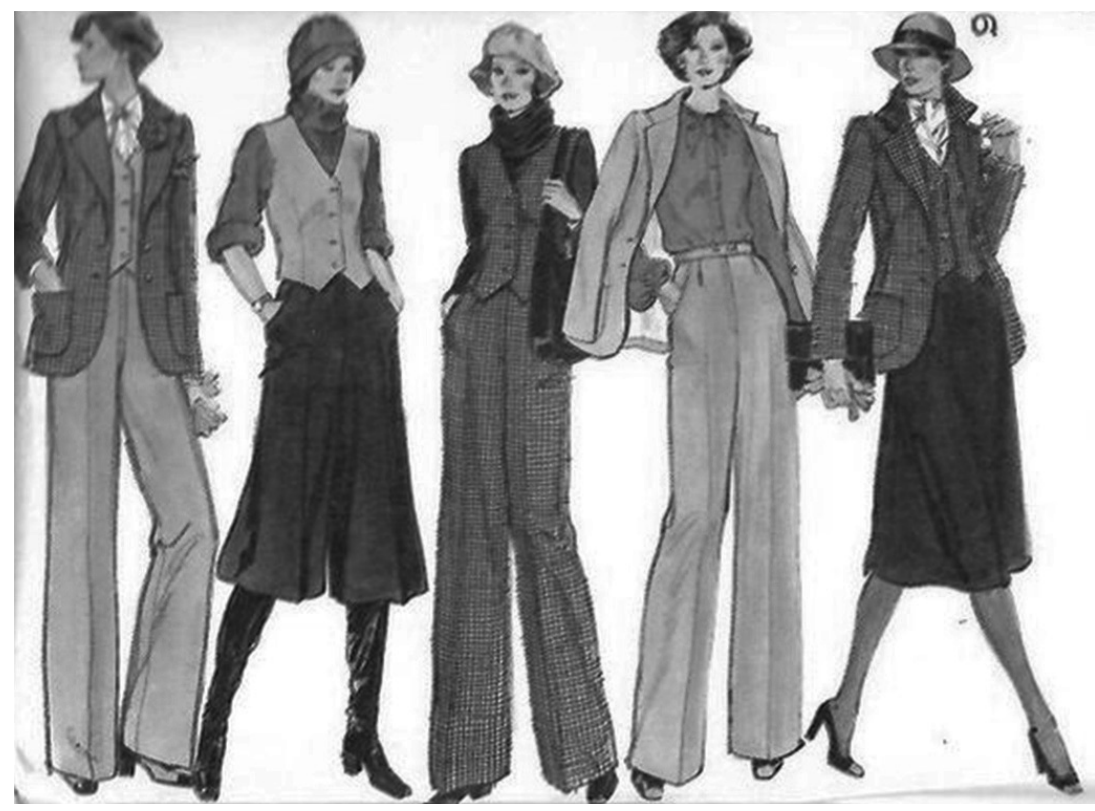

Figure 17.1970s business clothing here there is a step from the fashion of the protest to the fashion of conformism and that is the mass sale. There appear shops that sell such fashion, as well as "one-day" designers who work hard in this style until it fades. Today The Incredibles, Marvelous and Hippies seem equally ridiculous against The Yuppies. The fashion industry never lost - it's always profited from youth fashion in the 1960s, especially because then the young (the teenagers - see Figure 15) are its main users. Another factor that indirectly contributes to this is that women's emancipation then grows extremely - women are no longer so fanatical and do not regard such a tribute to fashion as the youth.

by his contemporaries with a scandal have evolved and turned into comfortable ladies' pants and imagine (!) even jeans that women already wear not only at home and when they are doing sports, but also walking with them at work. In this way, the sport and tourist clothes enter the everyday life and pave the way for the sport line in the rest of the fashion area. Particularly important for this is the designer Luis Dell'Olio, born in 1948, who, together with Donna Karen, develops original sportswear styles, turning them as O'Hara [6] says into "modern and comfortable clothes with a clean line" and thus opens the way to many other designers (Figure 13, 14). 
The second breakthrough in children's fashion. While in the first half of the century it is strictly distinct, but still a work of individual designers, children's fashion is becoming the subject of well-developed marketing research, powerful factory production and wholesale. In the United States, the first specialized children's and baby clothes stores are set up to meet the needs of the baby boomers that are soon to be transported across the ocean - originally in London, then in Paris and then across Europe. The men's costume and shape is already established and becomes almost constant, but even though it is timidly beginning to change, the most noticeable are the use of colored fabrics. If, in the 1930s, the replacement of black with brown is considered a courageous step, now, mainly youth, begins to wear green, blue-green and light blue men's jackets and trousers. This leads to the next, avalanche-like changes in fashion.

The third breakthrough is differentiation and special treatment for business clothing, a trend that clearly emerges in the early 1970s when more and more women occupy well-paid jobs - previously a privilege of men only. This fact places women's business clothing as an essential part of the fashionable landscape without, of course, being designed solely for women. According to O'Hara [7]: "It is made up of tailor-made suits - skirts and jackets, often made of fine striped fabric combined with a men's shirt and tie or with a blouse and a bow tie or a silk scarf tied around the neck. Bleaches are becoming popular in both daily and evening wear. It is worn both narrow and wide skirts or trousers" (Figure 17).

In spite of all, the main problem of the post-war decades remains - to find the complete balance between volume and line in the women's ensemble. Variants are possible - line overhang or volume predominance, but this often leads to temporary and unsustainable decisions. We will immediately analyze the most complicated case - the issue of partial refusal, but with a tendency to balance. A wonderful example of this gives us the use of the surrealist painter's ideas made in painting, and then with creative "deep" processing, transferring these artistic and picturesque ideas in the design of the ladies' costume. A very typical example of this is the transfer of surrealistic practices as an attempt to find the balance in solving the dilemma „line - volume" in ladies' costume.

\section{CONCLUSION}

Thanks to the immense historic momentum and good masters, as well as the creative conditions, France remains a lawmaker in high fashion, but the emphasis is now shifting to America, which relies on the huge mass production and the advertising industry as well. People who will be influential today are born in the 1990s, but for the time being, there are still no names to darken the glory of their predecessors. The "loophole / volume" dilemma due to the fact that there is no definitive once-and-for-all solution, awaits the individual bright and memorable personal decisions that future designers will apply, relying on both the implication in fashion and the solutions proposed by their predecessors.

\section{REFERENCES:}

[1] Kertakova, M. (2018). Analiza rada jednih od najeminentnijih modnih kreatora koji su radili u prvoj polovini 20. veka - Žak Duce, Pol Poare, Madeline Vionet, Mariano Fortuni i Madrazo i Žana Paken. Tekstilna industrija, 66(4), 35-44

[2] As an example, the successful collaboration between prominent French artists and designers of ladies fashion can be mentioned. A very prominent example of such cooperation is Picasso's work, who creates the damasks of Chanel's fabrics, and the collaboration between Salvador Dali and Elsa Schiaparelli.

[3] See Dimitrova-Popska, quote., p.184.

[4] There again, p.187.

[5] Elastic garments, considered to be part of the underwear, covering the feet, legs and body to the waist, became an alternative to ladies' socks in the 1960 s - easy to wear and hold, and no need for belt and garter. In the 1970s, all women wear tights that the industry is struggling to offer in different sizes, colors and patterns. This product becomes a major part of both winter and summer women's suits. The 80 s became the kingdom of unimaginably colorful and richly decorated with colored threads of lace, sequins and tights. Appearing in the 1960s, lace patterned pantyhoses are popular even today. Very common at the end of the twentieth and the beginning of the $21^{\text {st }}$ century remained the tights and striped pantyhose and hand-painted. Reports are according to O'Hara, quote. co., p. 218.

[6] O'Hara, quote., p. 65.

[7] There again p.84. 


\section{BIBLIOGRAPHY:}

- Boucher, François \& Deslandres, Yvonne. 20,000 Years of Fashion: The History of Costume and Personal Adornment. „Harry N. Abrams", New York, 1987.

- Шарлотта, Зелинг. Мода. Век модельеров. 1900 - 1999. „Konemann”. Koln, 2000

- $\quad$ Ермилова Д.Ю. История домов моды. „Академия", Москва, 2003.

- Дудникова, Галина Петровна. История костюма. „Феникс". Ростов на Дону, 2005.
- Барт, Ролан. Системата на модата.

„Агата-А“, София, 2005

- Димитрова-Попска, Пенка. История на костюма и орнамента. „Техника“, София, 2003

- О) Хара, Джорджина. Енциклопедия на модата. „Библиотека 48“, София, 1995

Rad primljen: 14.08 .2019 .

Rad prihvaćen: 10.09.2019. 